\title{
Rapid ecological assessment of mammals from a locality of middle basin at Palmar River, Zulia state, Venezuela
}

\author{
Belkis A. Rivas \\ Instituto Nacional de Salud Agrícola Integral-INSAI, Ministerio de Agricultura y Tierra, Pueblo Llano, CP 5125. Mérida, Venezuela; and \\ Fundación La Salle de Ciencias Naturales, Museo de Historia Natural La Salle, Apartado Postal 1930, Caracas 1010-A, \\ Venezuela.belkisarivas@gmail.com
}

\begin{abstract}
Arnaldo Ferrer
Fundación para el Desarrollo de las Ciencias Físicas, Matemáticas y Naturales, FUDECI. Palacio de las Academias, Edif. anexo, piso 2, Av. Universidad de Bolsa a San Francisco, CP 185, and Fundación La Salle de Ciencias Naturales, Museo de Historia Natural La Salle, Apartado Postal 1930. Caracas, Venezuela.
\end{abstract}

\section{Olga L. Herrera-Trujillo}

Pontifícia Universidade Católica do Rio Grande do Sul (PUCRS), Laboratório de Biologia Genômica e Molecular, Av. Ipiranga 6681, Porto Alegre, RS 90619-900, Brazil; Fundación para el Desarrollo de las Ciencias Físicas, Matemáticas y Naturales, FUDECI. Palacio de las Academias, Edif. anexo, piso 2, Av. Universidad de Bolsa a San Francisco, CP 185; Fundación La Salle de Ciencias Naturales, Museo de Historia Natural La Salle, Apartado Postal 1930. Caracas, Venezuela.

\section{David A. Prieto-Torres}

Eje BioCiencias; Centro de Modelado Científico de la Universidad del Zulia (CMC-LUZ), and Museo de Biología de La Universidad del Zulia (MBLUZ). Facultad Experimental de Ciencias, CP 4004. Maracaibo, Venezuela.

Abstract. Here we present the results from a rapid ecological assessment of mammals within Campo Boscán, located in the middle basin of the Palmar River in Zulia state, Venezuela. Records for species inventories were obtained from mist-nets and traps surveys and direct observation across three-vegetation types; we also include data from surveys to local communities. We identified 47 mammal species-representing 24 families and nine orders-, including the first record of the Hairy Big-eared Bat (Micronycteris hirsuta) for the Maracaibo Lake Depression region. Orders Chiroptera, Rodentia and Carnivora represented the most diverse and abundant taxa. Insectivores and carnivores were the most diverse trophic groups. Approximately $13 \%$ of the species are included within some threat category. Our results can be used for developing future monitoring programs in order to increase the knowledge on terrestrial vertebrates and biodiversity in general within the region. Key words: Ecology, species richness, mammals, Maracaibo Lake Depression, Zulia state.

\section{Introduction}

The first step for studying biodiversity is the assessment of species richness -and its space and time dimensions- given that this information represents the most important knowledge resource for developing systematic conservation planning; including its management and monitoring (Sánchez et al. 2004, Martins et al. 2016). In this sense, information regarding presence/absence, abundance and diversity of species, especially mammals, has been fundamental for further understanding other important ecological parameters such as population dynamics, communities' structure and ecological processes (e.g., dispersion, pollination), as well as to identify and assess biodiversity loss (Voss \& Emmons 1996, Wright et al. 2000, PrietoTorres et al. 2011, Martins et al. 2016).

In Venezuela, knowledge about the taxonomy and biogeography of mammals has considerably increased recently, including a complete and updated list (Linares 1998, Sánchez \& Lew 2012). According to a recent update on mammals of the world from Wilson and Reeder (2005)- the total number of mammal species reported for Venezuela is 391; this includes 14 orders, 47 families and 184 genera (Sánchez \& Lew 2012, Quiroga-Carmona \& Woodman 2015). However, despite these contributions, diverse studies have shown that species diversity values are evidently an underestimation (e.g., Ceballos et al. 2002, Sánchez and Lew 2012), suggesting the existence of significant knowledge gaps and absence of studies in numerous regions and habitats, especially in the northwest region of the country (e.g., Prieto-Torres et al. 2011, 2015a, b).

In this sense, the Maracaibo Lake Depression (MLD; Figure 1) -located in the Zulia state (northwest Venezuelan)- is considered a unique and important bioregion in the country, due to its climatic, geologic and ecological (including species diversity) characteristics (e.g., PDVSA 1993, MARN 2000, Rivas 2006, Rodriguez et al. 2010, Prieto-Torres et al. 2011). The most up-to-date information about this region indicated an approximate of 160 mammal species (representing 35 families and 11 orders), which represent $\sim 83$ and $\sim 41 \%$ of all mammal species reported for Zulia state and Venezuela, respectively (Rivas 2006, Prieto-Torres et al. 2015b). Despite this bioregion offers great potential -from a taxonomic perspective- it has received

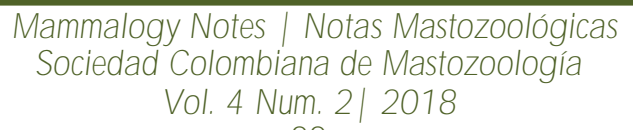


relatively little attention from ecologists and conservationists, as compared with Venezuelan Andes, the Central Coast Cordillera and the Guyana regions (e.g., Soriano et al. 1999, Machado \& Soriano 2007, Lasso et al. 2009, García et al. 2015, 2016). Furthermore, it is important to highlight that MLD has been affected, in the last 70 years, by agricultural and oilextraction activities, which has resulted in rapid modification and fragmentation of ecosystems (Duarte 1991, Romero \& Monasterios 1996, Colonnello \& Lasso-Alcala 2011). Based on this accelerated environmental deterioration (i.e., habitat loss), it is urgent to reliably assess the magnitude of these problems in local scales. This information will allow to design alternative measures for conservation, protection and adequate management of the natural areas within the region (e.g., Lasso et al. 2009, Rossi et al. 2016).

Here we present the results from the first rapid ecological assessment (REA; Lasso et al. 2009) of mammals from Campo Boscán, located in the middle Basin of the Palmar River on MLD. Our specific goals are: a) to provide a mammal species list for the study area, and b) to provide a brief characterization of the mammal species reported in terms of trophic level, distribution and conservation categories -both national and international. Additionally, we discuss about the importance of these results to increase the current knowledge of MLD' biodiversity and set the basis for future monitoring programs in the region.

\section{Materials and methods}

Study area. Campo Boscán is located southwest of Maracaibo city, in the middle basin of the Palmar River (Figure 1); which is part of the natural region known as "Altiplanicie de Maracaibo" (with a slopelower than 2\%) inside of the MLD province. Soils are relatively recent, or incipient, due the dry and semiarid climate of the area, and its surface corresponds mainly to sediments originating from Sierra de Perijá (COPLANARH 1975). The annual precipitation patterns are seasonal, with maximum rainfall peaks in October and May, while the average annual temperature is $27.7^{\circ} \mathrm{C}$ with a mean of $76 \%$ of relative humidity (SVMC 2008). Four vegetation types are present (Fernández et al. 2007, Rodriguez et al. 2010, Colonnello et al. 2014): (a) the lowland dry forests, which represent the dominant vegetation before deforestation; (b) the riparian evergreen forests, located with lowest density in the floodplain of the Palmar River; (c) the intervened scrubs (with 2 to $6 \mathrm{~m}$ in height), which are located in non-flooded and abandoned pastures of highlands in the northeast sectors of Campo Boscán; and (d) the flooded and non-flooded grasslands (not included in our study) that correspond to artificial environments delimited by ridges and introduced pastures.

Data collection. In order to obtain a preliminary diversity estimation of mammals within the area, we performed a rapid ecological assessment (from 20 to 30 November 2004, with 8 days duration). Sampling methods included traps and mist-nets, as well as records obtained from direct observations and surveys to local communities. Collecting procedures were authorized by the Venezuelan Ministry of Environment under a scientific collection license and followed the ethical guidelines for animal research established by Latin American Mammalogy Network (RELAM, in Spanish).

First, for capturing small and medium non-volant mammals, we implemented three lineal transects (two in the lowland dry forests and one in the grassland/scrubs; Figure 1), where three types of catch traps (i.e., Tomahawk, Sherman and Victor [i.e., blow]) were placed properly baited (Tirira 1998, Prieto-Torres et al. 2011). Each transect had 36 Tomahawks, 36 Sherman and 36 blows traps, 10-15 m apart, alternately arranged. The traps were baited with a mixture made of peanut butter, sardines, and cornmeal (Tirira 1998, Rossi et al. 2016). These were checked daily in the morning, and all captured individuals were collected. For this method, the sampling effort was of 342 to 537 trap-nights in the lowland dry forests and the grassland/scrubs, respectively. Complementarily, a total of 11 mist nets (of 9-12 $\mathrm{m}$ in length) were used in order to capture bat species; these were placed only in the lowland dry forests and the riparian evergreen forests (Figure 1) with a sampling effort of 64 hours/mist nest. Third, medium- and large-sized species having diurnal and/or nocturnal activity were inventoried from censuses carried out at a constant speed (i.e., $\sim 1-1.5 \mathrm{~km} / \mathrm{h}$ ) along the transects at each sampling site. For each record, the following data was registered: species observed, number of individuals within the group (in the case of social species), detection method (visual or auditory), place and time of observation. In addition, occasional observations and indirect evidence (footprints, scats, nests, and carcasses) were also considered (e.g., Tirira 1998, Prieto-Torres et al. 2011, Rossi et al. 2016). Further, interviews with local people were conducted based on illustrations found in Linares (1998).

Each collected specimen was either prepared as skin, skull, and skeleton or fixed in 10\% formalin and later preserved in $70 \%$ alcohol. These specimens were deposited in the mammal collection of the Museo de Historia Natural La Salle (MHNLS), Caracas, Venezuela (Table 1). All specimens were identified according to Sánchez and Lew (2012), which represent the most updated list of mammals for Venezuela since Wilson and Reeder (2005). This last update incorporates new species'

\footnotetext{
Mammalogy Notes | Notas Mastozoológicas

Sociedad Colombiana de Mastozoología

Vol. 4 Num. 2| 2018
} 
descriptions (e.g., Sánchez-H et al. 2005), new records of species for the country, as well as the recent reviews of species and description of new genera (e.g., Emmons 2005, Larsen et al. 2007, Quiroga-Carmona \& Woodman 2015).

Data analyses. We estimated species rarefaction curves for species collected by both methods together (i.e., traps and mist nests). To test sampling sufficiency during the study, we estimated the species richness using the first order Jackknife and its respective confidence intervals, using program EstimateS 9.1.0 (Colwell 2013), considering as sampling unit each collecting day. These curves represent the cumulative number of species against the increase of collecting effort, obtained after 50 randomizations. The Jackniffe was used because it is easy to interpret, as it expresses the total estimated species richness through a relatively simple function of the number of rare species (Heltshe \& Forrester 1983).

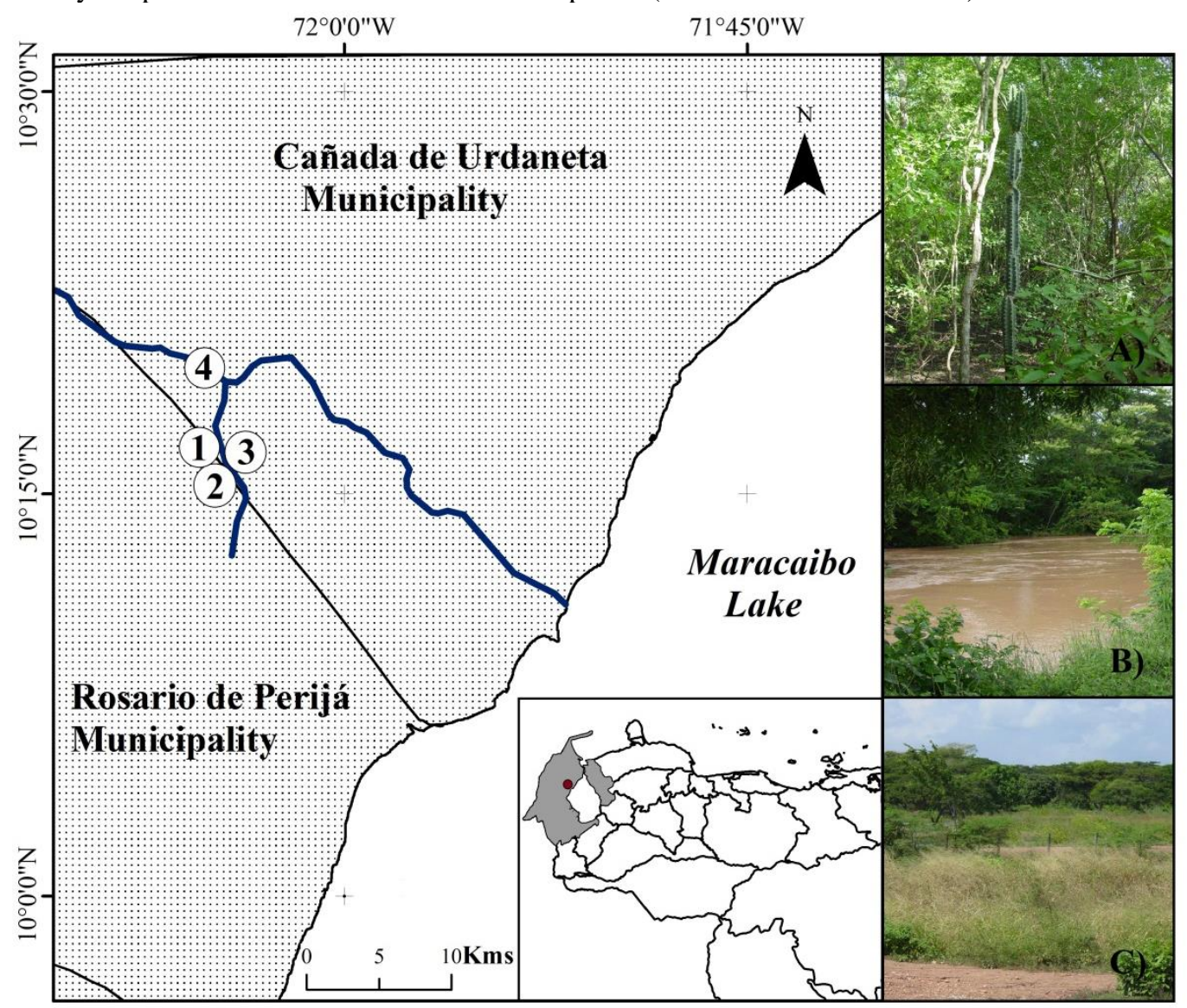

Figure 1. Geographical location of Campo Boscán locality, middle basin of the Palmar River, Zulia state-Venezuela. Numbers in map correspond to sampling localities: the lowland dry forests (1 and 3), grassland/scrubs (2), and the riparian evergreen forests (4). Blue line corresponds to the Palmar River. Photos (by Giuseppe Colonnello) correspond to sampling sites within Campo Boscán: a) lowland dry forests; b) riparian evergreen forests; and c) grassland/scrubs. We did not include the flooded and non-flooded grasslands due that raining season produced the inaccessibility to that vegetation type during the study.

In order to briefly characterize the mammal species, we provided information about the distribution, trophic levels and conservation categories for each species. First, all species were categorized based on their national distributional range (see Linares 1998) in: a) Widely Distributed (WD; those that occupy large and continuous extensions in the country); b) Broad Distributed (BD; those that occupy large but discontinuous extensions); c) Broad-Restricted (BR; those species that -despite occupy large areas- are restricted to a particular habitat or ecosystem); and d) Restricted (R; those distributed throughout two or three continuous bioregions). Then, we calculated the percentage of species corresponding to each trophic level (e.g., omnivore, frugivorous, granivorous, others). Finally, we indicated the conservation status to species at national (Rodríguez et al. 2015) and International levels (IUCN 2015), as well as indicate those species included in the Appendixes of the Convention on International Trade of Endangered Species of Wild Fauna and Flora (CITES 2011). 
Results

Species richness. For this study, we recorded 47 species belonging to nine orders and 24 families (Table 1). From these species, 32 were recorded during field work ( 28 collected and 4 observed), while 15 corresponded to species referred by local people. The greatest richness was observed for the Chiroptera order with 20 species (42.55\%), followed by Rodentia and Carnivora with nine (19.14\%) and eight species (17.02\%), respectively. However, the rarefaction curves (Figure 2) showed that the survey did not reach the asymptote, which indicates that more species are expected in the sampling site. The first order Jackknife estimator of species richness predicted a richness of 59.95 species, which was beyond the $95 \%$ confidence intervals of the observed cumulative curve (Figure 2).

Distribution, trophic levels and conservation categories. The Table 1 and Figure 3 shows a brief characterization -based on distribution, trophic levels and conservation categories- for the mammal community reported in Campo Boscán. Of all species recorded, $42(89.4 \%)$ occupy a broad geographic distribution $(\mathrm{WD}=18 ; \mathrm{BD}=14$; and $\mathrm{BR}=10)$, and five $(10.6 \%)$ were described with restricted distribution (Table 1$)$. We observed that $59 \%(n=28)$ of reported species correspond ecologically to riparian evergreen forests (with 20 species reported only in this vegetation), while $43 \%(\mathrm{n}=20)$ correspond to the lowland dry forests (with 13 exclusive species) and $17 \%(\mathrm{n}=8)$ to grassland (5 exclusive species). Furthermore, based on the trophic levels found, insectivorous species were the most dominant $(41.9 \%)$, followed by groups of carnivorous $(\mathrm{n}=6 ; 14 \%)$, omnivores $(n=5 ; 11.6 \%)$, frugivorous $(n=4 ; 9.3 \%)$ and granivorous $(n=4 ; 9.3 \%)$.

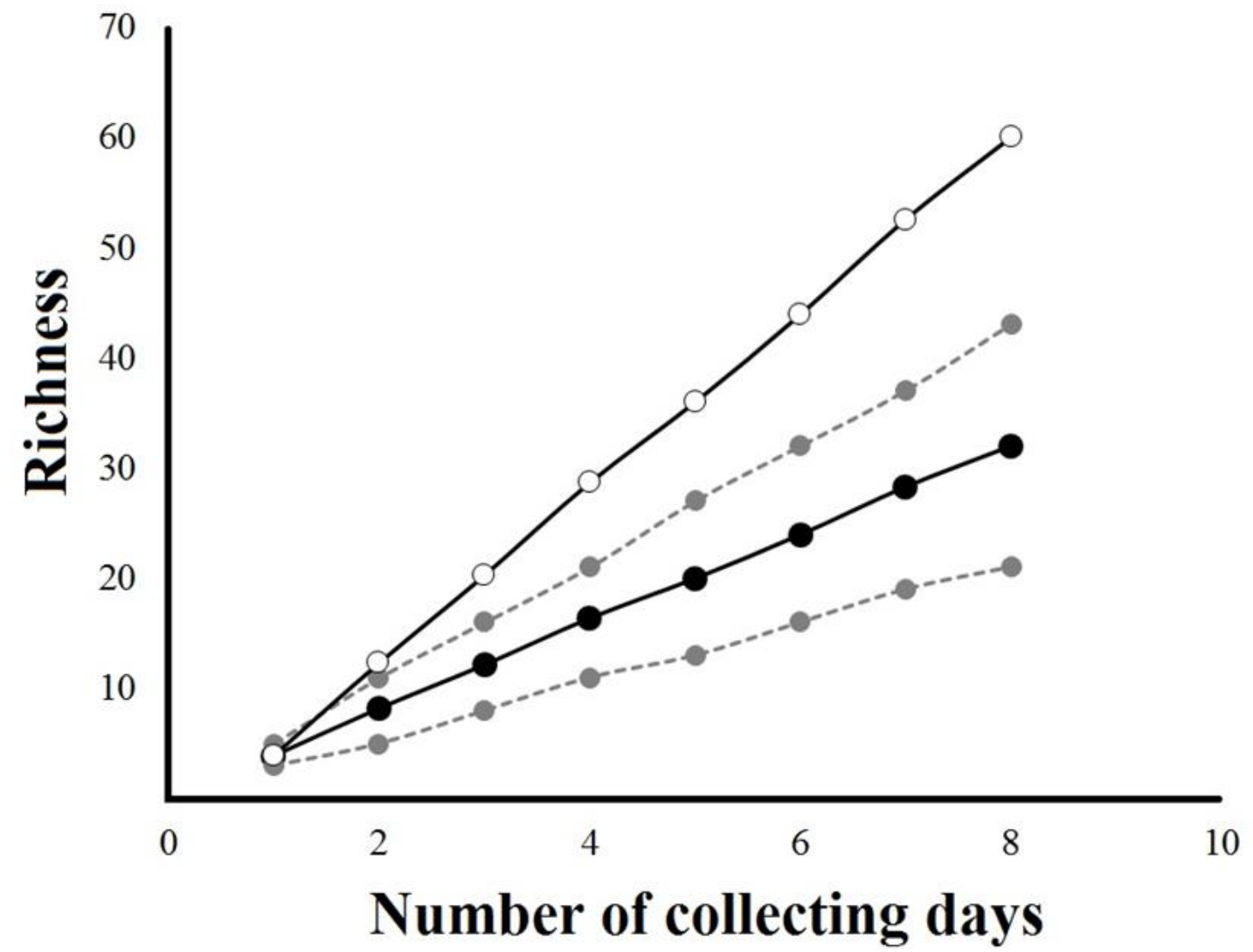

Figure 2. Rarefaction curves based on the cumulative number of species in relation to the number of collecting days at Campo Boscán, located in the middle basin of the Palmar River in Zulia state, Venezuela. Lines correspond to: general accumulative curve (black line and circles); the 95\% confidence interval (gray dotted lines), and the First order jackknife values (black lines with white circles).

Finally, according to the national and international conservation status of species, three species (i.e., Leopardus tigrinus, Lontra longicaudis, and Tapirus terrestris) are considered Endangered. From these, the species L. tigrinus, L. pardalis and L. longicaudis are include in the Appendix I of CITES, while T. terrestris, Puma concolor, and Bradypus variegatus are considered within the Appendix II. In addition, the Official Gazette of Venezuela Republic (1996) considers three of these species (L. pardalis, L. tigrinus, and L. longicaudis) as “Under Special Protection”. The remaining species ( -87 \%) do not have direct or indirect pressures of importance that promote their inclusion within some threat category.

\footnotetext{
Mammalogy Notes | Notas Mastozoológicas

Sociedad Colombiana de Mastozoología

Vol. 4 Num. 2| 2018
} 
Table 1. Composition of mammal species recorded at Campo Boscán in the middle Basin at Palmar River, Zulia State, Venezuela. The records were divided in $\mathrm{Co}=$ collected, $\mathrm{Obs}=$ observed, and $\mathrm{Ref}=$ Referenced by local people. We reported vegetation type (LDF: Lowland Dry Forest, REF: Riparian Evergeen Forest and G/S: Grassland/Scrubs), distribution (WD=Widely Distributed, BD= Broad Distributed, BR= Broad-Restricted, and

$\mathrm{R}=$ Restricted $)$, trophic level $(\mathrm{Omn}=$ omnivores, Ins= insectivorous, Frug= frugivorous, $\mathrm{Carn}=$ carnivorous, Gran= granivore, Foli $=$ folivore, Herb= herbivorous, Hema= hematophagus, $\mathrm{Pisc}=$ piscivorous, $\mathrm{Pol}=$ Polinivorous), and conservation status $(\mathrm{LC}=$ Least Concern, $\mathrm{DD}=\mathrm{Data} \mathrm{Deficient}, \mathrm{NT}=\mathrm{Near}$ Threatened, VU=Vulnerable; USP= Under Special Protection) for each species. Numbers in species name correspond to specimens deposited in the Museo de Historia Natural La Salle (MHNLS; see Species List in results).

\begin{tabular}{|c|c|c|c|c|c|c|c|c|}
\hline \multirow[b]{2}{*}{ Taxa } & \multirow[b]{2}{*}{ 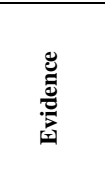 } & \multicolumn{3}{|c|}{ Species ocaurrence } & \multirow[b]{2}{*}{$\begin{array}{l}\text { Distribution } \\
\text { Range }\end{array}$} & \multirow[b]{2}{*}{$\begin{array}{c}\text { Trophic } \\
\text { level }\end{array}$} & \multicolumn{2}{|c|}{ Conservation Status } \\
\hline & & 筞 & 空 & $\frac{\mathscr{L}}{\omega}$ & & & 乙芯芯 & 预 \\
\hline \multicolumn{9}{|l|}{ DIDELPHIMORPHIA } \\
\hline Didelphis marsupialis Linnaeus, 1758 & $\mathrm{Co}, \mathrm{Obs}$ & & & & WD & Omn & $\mathrm{LC}$ & LC \\
\hline Marmosa robinsoni Bangs, 1898 & Co & $\mathrm{x}$ & & & WD & Ins-Frug & LC & LC \\
\hline Marmosa murina (Linnaeus, 1758) & Co & $\mathrm{x}$ & & & WD & Ins-Frug & $\mathrm{LC}$ & $\mathrm{LC}$ \\
\hline RODENTIA & & $\mathrm{x}$ & & $\mathrm{x}$ & & & & \\
\hline Hydrochoeris isthmius Goldman, 1912 & Ref & & & & BR & Herb & DD & $\mathrm{LC}$ \\
\hline Calomys hummelincki (Husson, 1960) & Co & & & $\mathrm{x}$ & $\mathrm{BD}$ & Omn & $\mathrm{LC}$ & $\mathrm{LC}$ \\
\hline Oecomys bicolor (Tomes, 1860) & Obs & & & $\mathrm{x}$ & WD & Gran-Frug & $\mathrm{LC}$ & $\mathrm{LC}$ \\
\hline Sigmodon alstoni (Thomas, 1881) & Co & $\mathrm{x}$ & & & $\mathrm{BR}$ & Herb-Gran & $\mathrm{LC}$ & LC \\
\hline Zygodontomys brevicauda (Allen \& Chapman, 1893) & Co & & & $\mathrm{x}$ & WD & Omn & $\mathrm{LC}$ & LC \\
\hline Cuniculus paca (Linnaeus, 1766) & Ref & & & $\mathrm{x}$ & WD & Frug-Foli & $\mathrm{LC}$ & LC \\
\hline Coendou prehensilis (Linnaeus, 1758) & Ref & & $\mathrm{x}$ & & WD & Gran-Foli & $\mathrm{LC}$ & $\mathrm{LC}$ \\
\hline Proechimys canicollis (Allen, 1890) & Co & & $\mathrm{x}$ & & $\mathrm{R}$ & Frug-Gran & LC & $\mathrm{LC}$ \\
\hline Notosciurus granatensis Humboldt, 1811 & Ref & $\mathrm{x}$ & & & WD & Omn & $\mathrm{LC}$ & $\mathrm{LC}$ \\
\hline LAGOMORPHA & & & $\mathrm{x}$ & & & & & \\
\hline Sylvilagus floridanus (Allen, 1890) & $\mathrm{Co}, \mathrm{Obs}$ & & & & WD & Foli & $\mathrm{LC}$ & $\mathrm{LC}$ \\
\hline CARNIVORA & & & & $x$ & & & & \\
\hline Urocyon cinereoargenteus (Schreber, 1775) & Ref & & & & $\mathrm{R}$ & Omn & $\mathrm{LC}$ & LC \\
\hline Leopardus pardalis (Linnaeus, 1758) & Obs & $\mathrm{x}$ & & & WD & Carn & $\mathrm{LC}^{*}$ & $\mathrm{Vu} / \mathrm{USP}$ \\
\hline Leopardus tigrinus (Schreber, 1775) & Ref & & $\mathrm{x}$ & & WD & Carn & $\mathrm{Vu}^{*}$ & $\mathrm{Vu} / \mathrm{USP}$ \\
\hline Puma concolor (Linnaeus, 1771) & Ref & & $\mathrm{x}$ & & WD & Carn & $\mathrm{LC}^{* *}$ & LC \\
\hline Puma yagouaroundi (E. Geoffroy Saint-Hilaire, 1803) & Ref & & $\mathrm{x}$ & $\mathrm{x}$ & WD & Carn & LC & $\mathrm{LC}$ \\
\hline Conepatus semistriatus (Boddaert, 1784) & Ref & & $\mathrm{x}$ & & WD & Omn & LC & LC \\
\hline Lontra longicaudis (Olfers, 1818) & Ref & & $\mathrm{x}$ & & $\mathrm{BR}$ & Carn & $\mathrm{NT}^{*}$ & $\mathrm{Vu} / \mathrm{USP}$ \\
\hline Procyon cancrivorus (Cuvier, 1798) & $\mathrm{Co}, \mathrm{Obs}$ & & $\mathrm{x}$ & & $\mathrm{BR}$ & Omn & LC & LC \\
\hline PRIMATES & & & $\mathrm{x}$ & & & & & \\
\hline Alouatta seniculus (Linnaeus, 1766) & Obs & & & & WD & Omn & $\mathrm{LC}$ & LC \\
\hline Cebus albifrons (Humboldt, 1812) & Obs & $\mathrm{x}$ & $\mathrm{x}$ & & $\mathrm{BD}$ & Ins-Frug & LC & LC \\
\hline CHIROPTERA & & & $\mathrm{x}$ & & & & & \\
\hline Rhynchonycteris naso (Wied-Neuwied, 1820) & Co & & & & BR & Ins & $\mathrm{LC}$ & $\mathrm{LC}$ \\
\hline Saccopteryx bilineata (Temminck, 1838) & Co & & $\mathrm{x}$ & & BR & Ins & $\mathrm{LC}$ & LC \\
\hline Noctilio albiventris Desmarest, 1818 & Co & $\mathrm{x}$ & $\mathrm{x}$ & & BR & Ins-Pisc & $\mathrm{LC}$ & LC \\
\hline Lonchorhina aurita Tomes, 1863 & Co & $\mathrm{x}$ & $\mathrm{x}$ & & BR & Ins & $\mathrm{LC}$ & LC \\
\hline Micronycteris hirsuta (Peters, 1869) & Co & & $\mathrm{x}$ & & $\mathrm{BR}$ & Ins-Frug & $\mathrm{LC}$ & LC \\
\hline Micronycteris megalotis (Gray, 1869) & Co & $\mathrm{x}$ & & & WD & Ins-Frug & $\mathrm{LC}$ & LC \\
\hline Micronycteris microtis Miller, 1898 & Co & $\mathrm{x}$ & & & $\mathrm{BD}$ & Ins-Frug & $\mathrm{LC}$ & LC \\
\hline Micronycteris minuta (Gervais, 1856) & $\mathrm{Co}$ & $\mathrm{x}$ & & & WD & Ins-Frug & $\mathrm{LC}$ & LC \\
\hline Micronycteris schmidtorum Sanbom, 1935 & Co & $\mathrm{x}$ & & & $\mathrm{BD}$ & Ins-Frug & LC & LC \\
\hline Gardnerycterys crenulatum (Geoffroy Saint Hilaire, 1810) & Co & $\mathrm{x}$ & & $\mathrm{x}$ & WD & Carn-Ins & $\mathrm{LC}$ & LC \\
\hline Phyllostomus discolor Wagner, 1843 & Co & $\mathrm{x}$ & & & WD & Ins-Frug & LC & LC \\
\hline Lophostoma silvicolum (D'Orbigny, 1836) & Co & & $\mathrm{x}$ & & WD & Ins-Frug & LC & LC \\
\hline Trachops cirrhosus (Spix, 1823) & Co & $\mathrm{x}$ & $\mathrm{x}$ & & BR & Carn-Ins & LC & LC \\
\hline Glossophaga longirostris Miller, 1898 & Co & & $\mathrm{x}$ & & WD & Poli-Ins & $\mathrm{DD}$ & LC \\
\hline Artibeus planirostris Spix, 1823 (23) & Co & $\mathrm{x}$ & $\mathrm{x}$ & $\mathrm{x}$ & WD & Frug & $\mathrm{LC}$ & LC \\
\hline Sturnira lilium (Geoffroy St. Hilaire, 1810) & Co & & $\mathrm{x}$ & & WD & Frug & $\mathrm{LC}$ & LC \\
\hline Desmodus rotundus (E. Geoffroy, 1810) & Co & & $\mathrm{x}$ & & WD & Hema & $\mathrm{LC}$ & LC \\
\hline Diphyllae caudata Spix, 1823 & Ref & $\mathrm{x}$ & $\mathrm{x}$ & & $\mathrm{BD}$ & Hema & $\mathrm{LC}$ & LC \\
\hline Molossus molossus (Pallas, 1766) & Co & & $\mathrm{x}$ & & WD & Ins & LC & LC \\
\hline Myotis nigricans (Schinz, 1821) & $\mathrm{Co}$ & & $\mathrm{x}$ & $\mathrm{x}$ & WD & Ins & LC & $\mathrm{LC}$ \\
\hline PILOSA & & & & $\mathrm{x}$ & & & & \\
\hline Bradypus variegatus Schinz, 1825 & Ref & & & & $\mathrm{BD}$ & Foli & $\mathrm{LC}^{* *}$ & LC \\
\hline Tamandua mexicana (Saussure, 1860) & Ref & & $\mathrm{x}$ & & $\mathrm{R}$ & Ins & $\mathrm{LC}$ & $\mathrm{LC}$ \\
\hline CINGULATA & & & $\mathrm{x}$ & & & & & \\
\hline Dasypus novemcinctus Linnaeus, 1758 & Ref & & & & WD & Ins-Omn & $\mathrm{LC}$ & $\mathrm{LC}$ \\
\hline PERISSODACTYLA & & & $\mathrm{x}$ & & & & & \\
\hline Tapirus terrestris (Linnaeus, 1758) & Ref & & & & WD & Omn & $\mathrm{Vu}^{* *}$ & $\mathrm{Vu}$ \\
\hline
\end{tabular}

\footnotetext{
Mammalogy Notes | Notas Mastozoológicas 


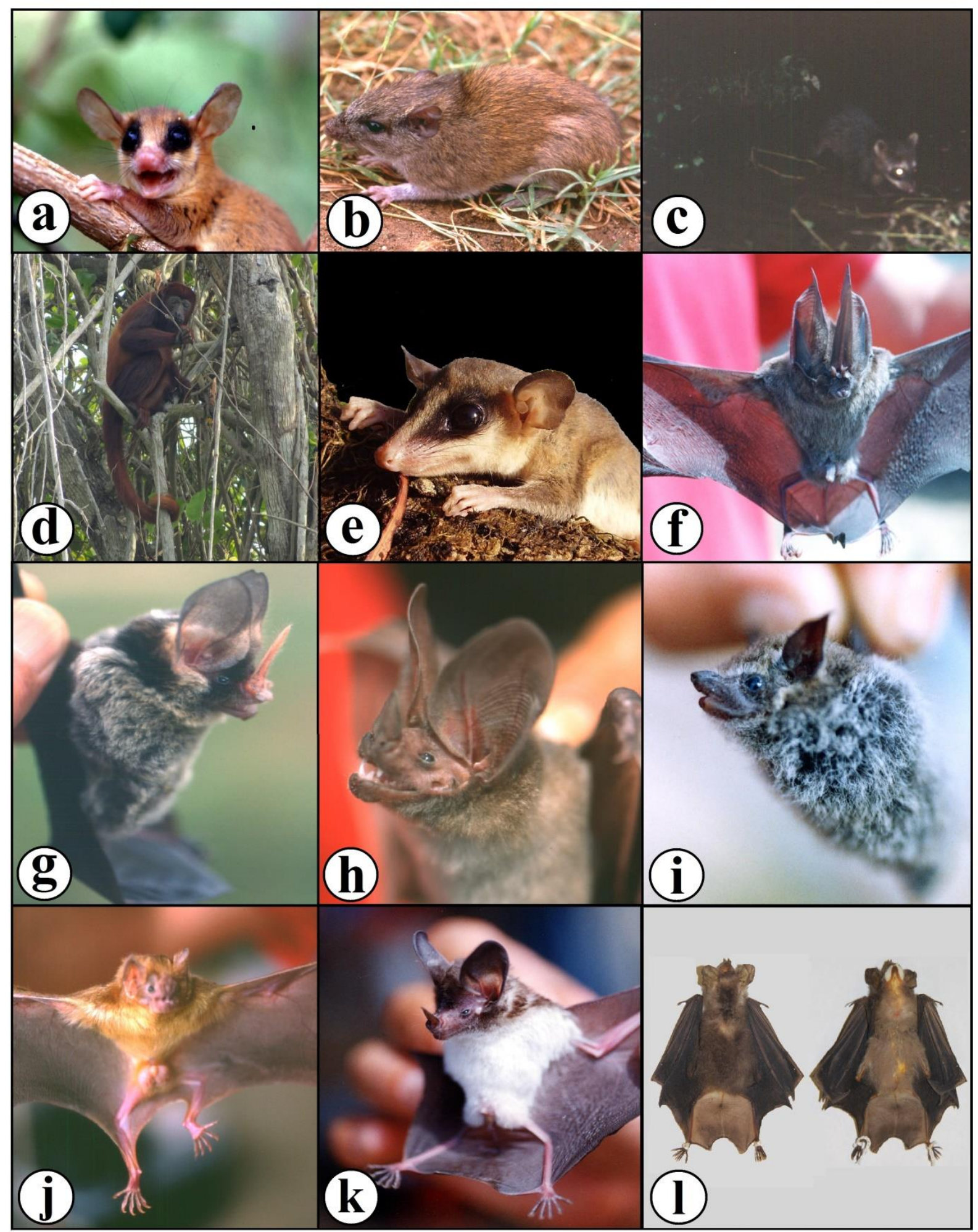

Figure 3. Representative mammal species inventoried in sampling sites at Campo Boscán, middle basin of the Palmar River in Zulia state, Venezuela. Letters correspond to: Marmosa robinsoni (a); Proechimys canicollis (b); Procyon cancrivorus (c); Alouatta seniculus (d); Marmosa murina (e); Lonchorhina aurita (f); Mimon crenulatum (g); Lophostoma silvicolum (h); Rhynchonycteris naso (i); Desmodus rotundus (j); Micronycteris schmidtorum (k); Micronycteris hirsuta (1). Photos of Oscar Lasso and Arnaldo Ferrer. 


\section{Discussion}

For MLD's mammals, studies on inventories, population dynamics and community structure are practically non-existent in the middle basin at Palmar River. In this context, the present study contributes to increase the current knowledge of biodiversity and threatened species in region. Mammals families and species reported in Campo Boscán represent $52.2 \%$ and $12.7 \%$ of the total reported for Venezuela, respectively (Sánchez \& Lew 2012); as well as the $63.2 \%$ and 33.6\%, respectively, for the Zulia state (Rivas 2006, Prieto-Torres et al. 2015b). Despite that these results can be described as satisfactory, it is important to note that only approximately $\sim 78 \%$ (considering the 15 species reported by local people) of richness predicted by the Jackknife richness estimator were recorded. This last fact was dueto the short sample period (a characteristic of REA's studies; Lasso et al. 2009), the climatic conditions that produced floods in the riparian evergreen forests (producing a lower sampling effort during the study), and capturing methods used (e.g., Voss et al. 2001, Martins et al. 2016). Unlike other vertebrates -that can be effectively poisoned, captured and/or hunted- most of mammals can only be inventoried by trapping, which could require in most cases long-term efforts to obtain a complete data (e.g., Voss et al. 2001, Prieto-Torres et al. 2011, García et al. 2015, 2016, Martins et al. 2016). This is the case of some forest canopy species (e.g., arboreal marsupials and rodents), which require of other additional techniques such as acoustic methods and camera traps (Ochoa et al. 2005, García et al. 2015, 2016, Martins et al. 2016); here not used due the logistical difficulties and resource unavailability.

All species documented have been previously reported for others areas in the Zulia state (e.g., Osgood 1910, 1912, MéndezA 1953, Pirlot1963, Handley 1976, Duarte 1991, MARN-PROFAUNA 1991, 1997, Viloria \& Calchi 1993, Sánchez et al. 1999, Rivas 2006, Prieto-Torres et al. 2011). However, the Hairy Big-eared Bat' specimen (Micronycteris hirsuta) herein reported, represents the first record of the species for MLD region (Prieto-Torres et al. 2015a). This species had only been reported for the state in Sierra of Perijá, on elevations up to 1,000 m. only (Prieto-Torres et al. 2015b). Consequently, it is expected that the recorded 47 species are not the only representatives within this local ity. In fact, survey's effort was carried out in the length of 10 days, less than in other surveys (e.g., Prieto-Torres et al. 2011, Martins et al. 2016); therefore, it is expected that by increasing the sampling effort throughout the four vegetation types, new species should be reported for the area (see Figure 2).

Despite the differences on sampling efforts for all vegetation types, the percentage of species reported associated with the riparian evergreen $(n=20 ; 42 \%)$ and lowland dry $(n=13 ; 28 \%)$ forests could be explained, on one hand, by the bats sampling (see below; Table 1) during the study. However, alternatively, results can be explained by the greater spatial heterogeneity of riparian habitats, which provide greater diversity of refuges and food (e.g., Machado et al. 2016). It is also possible to infer that the species richness observed in Campo Boscán is considerably high due the overlap of different environments (i.e., ecotones) in this region; this is evidenced by the presence of four species (Sylvilagus floridanus, Calomys hummelincki, Sigmodon alstoni, and Urocyon cinereoargenteus) defined as characteristic elements of dry forests and savannas. This mixed composition increases the biological importance of region (e.g., Costa et al. 2000, Joshi 2016, Machado et al. 2016), which emphasizes the need for its conservation in order to preserve the biodiversity of these fragments.

Most species of mammals in our study have wide distributions along Venezuela and some medium-size and large species were strongly associated with diverse ecotones - mainly dependent on water- for example L. longicaudis, Procyon cancrivorus, and Hydrochaeris isthmius. Felid species (Carnivora), such as Puma concolor and P. yagouaroundi, are mainly associated with riparian evergreen forest areas, but can expand their home range given their ability to occupy open areas with intervened covers such as pastures and crops (MARN-PROFAUNA 1997, Prieto-Torres et al. 2011, Machado et al. 2016). Furthermore, despite Primates are among the most endangered groups, it is important to note that there is few information on the ecology and conservation status of species such as Alouatta seniculus and Cebus albifrons in MLD' areas (Portillo \& Velásquez 2006). These species have broad phenotypic flexibility and occur in small forest fragments, which demonstrates a high capacity to adapt to environmental changes (Boubli et al. 2008, de la Torre et al. 2015). Therefore, although these species usually inhabit larger areas, its presence in areas outside close Protected Areas (i.e., Sierra Perijá and Juan Manuel National Parks) could be important for its preservation (Portillo \& Velásquez 2006).

Bat species composition and richness varied along sampling sites at Campo Boscán (Table 1). The high abundance of most common species -such as Noctilio albiventris, Desmodus rotundus and Glossophaga longirostris- could indicate the availability of resources for generalists such as roost sites and food sources (e.g., livestock for D. rotundus and artificial lakes stocked with fish for $N$. albiventris). This last idea is supported by the presence of varied species of insectivores, frugivores, nectivores, hematophages, and piscivores (Novaes \& Nobre 2009, Shapiro \& Bordignon 2014). In addition, the presence of individuals from the subfamily Phyllostominae - which are considered bio-indicators (Fenton et al.1992)- could indicate a fair ecosystem health, despite the level of perturbation observed, given that bats provide valuable ecosystem services such as

\footnotetext{
Mammalogy Notes | Notas Mastozoológicas

Sociedad Colombiana de Mastozoología

Vol. 4 Num. 2| 2018
} 
insect populations' control (including agricultural pests), seed dispersal, and plant pollination (e.g., Kelm et al. 2008, Kunz et al. 2011, Shapiro \& Bordignon 2014). However, further sampling is necessary at this site to assess the role of these species in the secondary succession and the regeneration of degraded forests in the area (Kelm et al. 2008, Kunz et al. 2011). Further, based on the high relative frequency observed for the common vampire bat (D. rotundus), a transmitter of bovine rabies (Baer 1982; Greenhall et al. 1983), future studies should be implemented regarding sanitary control to avoid economic loss.

In terms of conservation, unfortunately there is no other information about the extant wildlife found in the area; however, it is evident the negative effects of habitat loss and hunting over local wildlife populations. Forests have been reduced considerably, only leaving isolated relicts in almost the entire area (Duarte 1991, Romero \& Monasterios 1996, Rodríguez et al. 2010, Colonnello \& Lasso-Alcala 2011). Many mammal species are dependent on native vegetation cover, thus, fragmented and reduced habitats -such as Campo Boscán- can lose the original mammal community if species are not able to find the resources for long-term survival (Chiarello 1999, 2000, Machado et al. 2016). This is probably the case for species such as T. terrestris -considered locally extinct (IUCN 2015, Rodríguez et al. 2015) and the Brown Spider Monkey (Ateles hibrydus), a common species in other MLD's localities (Portillo \& Velásquez 2006), which was not observed or referenced during the study, as well as neither the armadillo (Cabassous centralis), deer (Mazama amaricana, M. bricenii, and Odocoileus cariacou) and peccaries (Pecari tajacu and Tayassu pecari) species -- all species reported as heavily hunted in the region (e.g., Prieto-Torres et al. 2011). In this sense, the information obtained suggests the need for implementation of improved conservation strategies focusing on the importance of minimizing impacts in the area.

Definitely, a single-species approach to conservation, management, and monitoring is insufficient to combat the threat to the overall biological diversity of an area (Joshi 2016). Thus, rapid ecological assessment and multi-species-based monitoring approaches are believed to be more reliable, timely, and informative in describing and measuring changes in populations, communities and biological diversity in general (Joshi 2016, Martins et al. 2016). In this sense, our results provide a valuable database in order to recognize and promote this area as an important wildlife resource; which currently have been affected by important problems related to the loss, fragmentation and degradation of habitats (Romero \& Monasterios 1996, Rodríguez et al. 2008, Colonnello \& Lasso-Alcalá 2011, Colonnello et al. 2014). This information can be used for the development of monitoring and conservation programs, promoting the recovery, reforestation and connectivity of forest patches -important for endangered species with large home-range such as L. pardalis, L. tigrinus and L. longicaudis. Additional studies on the abundance/distribution and status of wildlife species, also involving local communities and all stakeholders, from MLD is of supreme importance for securing long-term persistence of mammalian fauna in the area.

\section{Acknowledgements}

We would like to acknowledge the contributions of the Fundación La Salle de Ciencias Naturales, which provided financial and logistical support. Monica Chocrom by the assistance in fieldworks. Oscar Lasso and Giuseppe Colonnello kindly provided the photos of the specimens and sampling sites. Cristina Vallejo kindly reviewed the translation.

\section{References}

BAER, G. M. 1982. Historia natural de la rabia. México, Ed. La Prensa Médica Mexicana.

BOUBLI, J. P., et al. 2008. Alouatta seniculus. The IUCN Red List of Threatened Species 2008: e.T40642A10347360. Available in: http://dx.doi.org/10.2305/IUCN.UK.2008.RLTS.T40642A10347360.en. Downloaded on 16 December 2016.

CEBALLOS, G., et al. 2002. Mamíferos de Venezuela. Pp. 567-582 in Diversidad y conservación de los mamíferos del Neotrópico (Ceballos G \& Simonetti JA eds.), Comisión Nacional para el Conocimiento y Uso de la Biodiversidad - CONABIO y la Universidad Nacional Autónoma de México. Ciudad de México, México

CHIARELLO, A. G. 1999. Effects of fragmentation of the Atlantic forest on mammal communities in south-east Brazil. Biological Conservation 89:71-82.

CHIARELLO, A. G. 2000. Density and population size of mammals in remnants of Brazilian Atlantic Forest. Conservation Biology 14:1649-657.

CITES. 2011. Convention on International trade in endangered species of wild fauna and flora. Available in: http://www.cites.org/esp/app/appendices.shtml.

COLONNELLO, G. \& O. LASSO-ALCALÁ. 2011. Diagnóstico ambiental de la Cuenca del Lago de Maracaibo, Venezuela. Pp. X-Z in Informe para gestores y encargados de tomar decisiones (Volpedo AV, et al. eds.), RED CYTED 411RT0430. Buenos Aires, Argentina.

COLONNELlO, G., et al. 2014. Cambios en la composición de plantas asociadas a humedales como consecuencia de la intervención antrópica. Revista de la Facultad de Agronomía 31:190-214.

COLWELL, R. K. 2013.EstimateS: Statistical estimation of species richness and shared species from samples. Version 9.1.0. Sinauer Associates, Sunderland, Massachusetts.

COPLANARH. 1975. Atlas Inventario Nacional de Tierras. Región del Lago de Maracaibo. Ministerio de Agricultura y Cría, Centro Nacional de Investigaciones Agropecuarias, Caracas, Venezuela 90.

COSTA, E. P., et al. 2000. Biogeography of South American forest mammals: endemism and diversity in the Atlantic Forest. Biotropica 32:872-881.

DE LA TORRE, S., et al. 2015. Cebus albifrons. The IUCN Red List of Threatened Species 2015.e.T39951A81236767. Available in: http://dx.doi.org/10.2305/IUCN.UK.2015.RLTS.T39951A81236767.en. Downloaded on 16 December 2016.

DUARTE, M. 1991. Contribución al conocimiento de la fauna de mamíferos del Estado Zulia (Thesis dissertation). Zulia state, Venezuela: Universidad del Zulia. 126 pp.

EMMONS, L. H. 2005. A revision of the genera of arboreal Echimyidae (Rodentia: Echimyidae, Echimyinae), with descriptions of two new Genera. Pp. 247-309 in Mammalian diversification from chromosomes to phylogeography (A Celebration of the Career of James L. Patton) (Lacey EA \& Myers P eds.). USA: University of California Publications. Zoology, Vol. 133.

FENTON, M. B., et al. 1992. Phyllostomid bats (Chiroptera: Phyllostomidae) as indicators of habitat disruption in the Neotropics. Biotropica 24:440-446.

FERNÁNDEZ, A., et al. 2007. Inventario de la diversidad florística de un sector del curso medio del río Palmar, estado Zulía. Revista de la Facultad de Agronomía (LUZ) 24: 415-421.

GARCÍA, F. J., et al. 2016. Mamíferos de la Sierra de Aroa, estado Yaracuy, Venezuela: Listado taxonómico y la importancia de su conservación. Memoria de la Fundación La Salle de Ciencias Naturales 73:17-34.

\section{Mammalogy Notes | Notas Mastozoológicas \\ Sociedad Colombiana de Mastozoología \\ Vol. 4 N um. 2| 2018}




\section{Inventarios | Inventories}

GARCÍA, F. J., et al. 2015. Murcielagos (Mammalia: Chiroptera) asociados con una cueva en el Parque Nacional Yurubí, Sierra de Aroa, estado Yaracuy, Venezuela. Caldasia 37:381-391.

GREENHALL, A. M., et al. 1983. Desmodus rotundus. Mammalian Species 202:1-6.

HANDLEY, C. 1976. Mammals of the Smithsonian Venezuelan Project Brigham Young University science bulletin. Biological series 20:1-89.

HELTSHE, J.F., \& N. E. FORRESTER. 1983. Estimating species richness using the jackknife procedure. Biometrics 39:1-11.

IUCN. 2015. The IUCN Red List of Threatened Species. Version 2015-4. http://www.iucnredlist.org Accessed 14.12.2016.

JOSHI, R. 2016. Mammalian fauna of Rajaji National Park, India: a review on ecological observations and checklist. Check List 12:1892.

KELM, D. H., et al. 2008. Effects of artificial roosts for frugivorous bats on seed dispersal in a Neotropical forest pasture mosaic. Conservation Biology 22:733-741.

KUNZ, T. H., et al. 2011. Ecosystem Services provided by bats. Annals of the New York Academy of Sciences 1223:1-38.

LARSEN, P. A., et al. 2007. Phylogenetics and phylogeography of the Artibeus jamaicensis complex based on cytochrome-b DNA sequences. Journal of Mammalogy 88:712727.

LASSO, C. A., et al. 2009. Evaluación rápida de la biodiversidad de los ecosistemas acuáticos de la cuenca alta del Río Cuyuní, Guayana Venezolana. Conservation International. Caracas, Venezuela 235.

LINARES, O. J. 1998. Mamíferos de Venezuela. Sociedad Conservacionista Audubon de Venezuela. Caracas, Venezuela 691.

MACHADO, M. \& P. SORIANO. 2007. Temperature regulation in two insectivorous bats (Myotis keaysi and Myotis oxyotus) from the Venezuelan Andes. Ecotropicos 20: 4554.

MACHADO, F. S., et al. 2016. Diversity of medium-sized and large mammals from Atlantic Forest remnants in southern Minas Gerais state, Brazil. Check List 12: 1962.

MARN. 2000. Primer Informe de Venezuela sobre Diversidad Biológica. Ministerio del Ambiente y de los Recursos Naturales, Oficina Nacional de Diversidad Biológica. Caracas, Venezuela 227.

MARN-PROFAUNA. 1991. Inventario de Fauna Silvestre Cuenca Alta del Río Palmar-Edo. Zulia, Sub-cuenca Río Lajas-Río Palmar, unpublished report, Ministerio del Ambiente y los Recursos Naturales and Servicio autónomo PROFAUNA, Maracay, Venezuela 25.

MARN-PROFAUNA. 1997. Inventario de Fauna en el área de influencia Terminal de Carga de Buques de Carbones del Guasare, S.A, unpublished report, Ministerio del Ambiente y los Recursos Naturales and Servicio autónomo PROFAUNA, Maracay, Venezuela 77 p.

MARTINS, T., et al. 2016. Large and medium-sized mammals in the urban park Cinturão Verde, Cianorte, northwestern Paraná. CheckList 12:1851.

MÉNDEZ-A, J. 1953. Estudio de los mamíferos colectados por la Sociedad de Ciencias Naturales La Salle en la Región de Perijá. Memoria Sociedad Ciencias Naturales La Salle 13:81-120.

NOVAES, R. L. M. \& C. C. NOBRE. 2009. Dieta de Artibeus lituratus (Olfers, 1818) em área urbana nacidade do Rio de Janeiro: frugivoria e novo registro de folivoria. Chiroptera Neotropical 15:487-493.

OCHOA, J., et al. 2005. Evaluación ecológica rápida de las comunidades de mamíferos en cinco localidades del Delta del Orinoco, Venezuela. Interciencia 8:466-475.

OSGOOD, W. 1910. Mammals from the coast and island of northern South-America. Fieldiana Museum Natural History Zoology. Service Publication 149:23-32.

OSGOOD, W. 1912. Mammals from western Venezuela and Eastern Colombia.Fieldiana Museum Natural History Zoology. Service Publication 155:33-66.

PDVSA. 1993. Imagen Atlas de Venezuela: Una visión espacial. Petróleos de Venezuela S.A. Caracas, Venezuela 271.

PIRLOT, P. 1963. Algunas consideraciones sobre la ecología de los mamíferos del oeste de Venezuela. Kasmera, Facultad Medicina Universidad del Zulia 1:169-214.

PORTILLO, C. \& Y. VELÁSQUEZ. 2006. Disponibilidad y estado del hábitat de tres especies de primates amenazadas de extinción en la sierra de Perijá: Generación de información biogeográfica base para el Diseño de proyectos de investigación para la conservación [unpublished report], Asociación Civil Provita, Caracas, Venezuela 35.

PRIETO-TORRES, D., et al. 2015a. First record of Nasua nasua (Linnaeus, 1766) (Mammalia: Carnivora: Procyonidae) for the Zulia state, western Venezuela. CheckList 11: 1790.

PRIETO-TORRES, D. 2015b. Lista actualizada de los mamíferos del Estado Zulia: Análisis espacial y comentarios de los registros de ocurrencia de las especies. On: XI Congreso Venezolano de Ecología, Margarita Venezuela: Sociedad Venezolana de Ecología.

PRIETO-TORRES, D., et al. 2011. Lista preliminar de mamíferos no voladores en tres localidades de la vertiente suroriental de la Sierra de Perijá, Estado Zulia-Venezuela. Boletín del Centro de Investigaciones Biológicas 45:21-34.

QUIROGA-CARMONA, M. \& N. WOODMAN. 2015. A new species of Cryptotis (Mammalia, Eulipotyphla, Soricidae) from the Sierra de Perijá, Venezuelan-Colombian Andes. Journal of mammalogy 96:800-809.

RIVAS, B. 2006. Diversidad y distribución de la mastofauna de la región zuliana. On: Libro de Resúmenes del II Congreso Colombiano de Zoología, Santa Marta, Colombia. 216. RODRÍGUEZ, J. P., et al. 2015. Libro Rojo de la Fauna Venezolana. Caracas Venezuela: Provita y Fundación Empresas Polar. Available in: animalesamenazados.provita.org.ve RODRÍGUEZ, J. P., et al. 2010. Libro Rojo de los Ecosistemas Terrestres de Venezuela. Asociación Civil Provita. Caracas, Venezuela 324.

ROMERO, L. \& M. MONASTERIO. 1996. Los costos ecológicos y socioeconómicos del autoabastecimiento lechero. El caso del Sur del Lago de Maracaibo. Revista Agroalimentaria 2:7.

ROSSI, R. V., et al. 2016. Rapid assessment of nonvolant mammals in seven sites in the northern State of Pará, Brazil: a forg otten part of the Guiana Region. Mammalia 2016

SÁNCHEZ, F., et al. 2004. Inventario de mamíferos en un bosque de los andes centrales de Colombia. Caldasia 26:291-309.

SÁNCHEZ, J. \& D. LEW. 2012. Lista actualizada y comentada de los mamíferos de Venezuela. Memoria de la Fundación La Salle de Ciencias Naturales 173-174:173-238.

SÁNCHEZ, J., et al. 1999. Inventario de Fauna en el Refugio de Fauna silvestre y Reserva de Pesca "Cienaga Los Olivitos" Sectores Caño Nuevo, Las Callejuelas, Las Tareas Caño Oribor, unpublished report, Ministerio del Ambiente y los Recursos Naturales and Servicio autónomo PROFAUNA, Maracay, Venezuela 33.

SÁNCHEZ-H., C., et al. 2005. New species of Sturnira (Chiroptera: Phyllostomidae) from Northern South America. Journal of Mammalogy 86:866-872.

SHAPIRO, J. T. \& BORDIGNON M. O. 2014. Bat (Chiroptera) assemblages in three Cerrado fragments of Mato Gros so do Sul, southwestern Brazil. CheckList 10:1380-1386.

SORIANO, P., et al. 1999. Biogeographic analysis of the mammal communities in the Venezuelan Andes. Interciencia 24:17-25.

SVMC (SERVICIO VENEZOLANO DE METEOROLOGÍA Y CLIMATOLOGÍA). 2008. Servicio de Meteorología de la Aviación. Estación Maracaibo, Aeropuerto Internacional La Chinita. Base Aérea Rafael Urdaneta.

TIRIRA, D. 1998. Técnicas de campo para el estudio de mamíferos silvestres. Pontificia Universidad Católica del Ecuador, Quito. Publicación Especial 1: 93-125.

VILORIA, A. L. \& R. CALCHI. 1993. Una lista de los vertebrados vivientes de la Sierra de Perijá, Colombia y Venezuela. Biollania 9:37-69.

VOSS, R. S. \& L. H. EMMONS. 1996. Mammalian diversity in Neotropical lowland rainforests. A preliminary assessment. Bulletin of the American Museum of Natural History 230:1-115.

VOSS, R. S., et al. 2001. The mammals of Paracou, French Guiana: a Neotropical lowland rainforest fauna, part 2: Nonvolant species. Bulletin of the American Museum of Natural History 263:1-236.

WILSON, D. E. \& D. M. REEDER. 2005. Mammal species of the world: a taxonomic and geographic reference. $3^{\mathrm{a}}$ edición, The Johns Hopkins University Press, Vols I y II, USA.

WRIGHT, S. J., et al. 2000. Poachers alter mammal abundance, seed dispersal, and seed predation in a Neotropical forest. Conservation Biology 14:227-239.

\section{Mammalogy Notes | Notas Mastozoológicas \\ Sociedad Colombiana de Mastozoología \\ Vol. 4 N um. 2| 2018}


Appendix 1. Taxonomic comments and most relevant characters used to identify the specimens reported in this study. All specimens collected were deposited at the Museo de Historia Natural La Salle (MHNLS).

\section{Phylum Chordata \\ Class Mammalia}

Order Didelphimorphia Hill, 1872

Family Didelphidae Gray, 1821

Didelphis marsupialis (Linnaeus, 1758) -- Gardner (1973); Cerqueira (1985)

Description: Dorsal color grayish mottling of dirty white or yellow, and dark limbs. Belly similar to the back with pale tones. No white facial marking. Ears large and entirely black. Tail naked of black color with white tip. Medium size (317 - 465 $\mathrm{mm}$ ) with tail length equal to the body.

Marmosa robinsoni Bangs, 1898 -- O'Connell (1983)

Material examined: MHNLS M-11927-11933 (Figure 3a)

Description: Dorsal pelage long and dense, brown to yellowish brown; ventral pelage yellowish to white -usually with some hairs gray. Tail with fine and either unpigmented or weakly pigmented hairs. Postorbital processes distinctly beaded on margins, but less prominent and appearing to be positioned farther behind orbits. Postorbital ridges converge towards the midline as they extend posteriorly over parietals. Posterolateral palatal foramina usually greater than $0.5 \mathrm{~mm}$ in width. Postorbital processes not exceptional, breadth across tips of processes less than 10 $\mathrm{mm}$ and not wider than breadth of rostrum at anterior base of the zygomatic arch. Cranium with prominent supraorbital ridges and laterally projecting postorbital processes.

Marmosa murina (Linnaeus, 1758) -- Thomas (1911); Tate 1933; Cabrera 1959; Patton \& Costa (2003)

Material examined: MHNLS M-11934 (Figure 3e)

Description: Dorsal pelage dark brown; head clearer than body with a well-defined black eye ring. Postorbital processes broadly triangular in outline from above; postorbital ridges approximately parallel as they extend posteriorly over parietals; posterolateral palatal foramina minute (less than $0.5 \mathrm{~mm}$ in width). Tail with sparse, short, and moderately pigmented.

\section{Order Rodentia Bowdich, 1821}

Family Sciuridae Fischer de Waldheim, 1817

Notosciurus granatensis Humboldt, 1811 -- Hall (1981); Cabrera (1961); Nitikman (1985)

Description: Dorsal pelage olivaceous brown to orange coloration, with short, dense and loose coat. Ventral hairs of a single color (orange) throughout, which are clearer than dorsal hairs. Eyes with an orange eye-ring. Ears brown, short and rounded. Tail very long and hairy, with the base of black color, and orange tip.

Family Cricetidae Fischer, 1817

Calomys hummelincki (Husson, 1960) -- Hershkovitz (1962); Handley (1976); Pérez-Zapata et al. (1987); Garcia et al. (1999); Martino \& Capanna (2002) Material examined: MHNLS M-11904, MHNLS M-11905

Description: Short and soft pelage; dorsum bright buffy coriaceous. Head is similar to the back but with a clear spot behind the ears. Ears big, rounded and gray. Tail shorter than $60 \mathrm{~mm}$ (less than $45 \%$ of total length), naked and partially bicolored.

Oecomys bicolor (Tomes, 1860) -- Musser \& Patton (1989)

Description: Recognizable chiefly by small size (averaging only larger than $O$. rutilus), combined with white under parts and relatively short tail that bears moderate terminal tuft. Dorsal fur ranges from ochraceous tawny (nearly orange brown) to rufous brown, finely mixed with dark brown over middle dorsum and becoming slightly paler along lower sides of head and body, a bright buffy gray. Dorsal pelage is short for body size ( $3-6 \mathrm{~mm}$ over the middle rump). Terminal tail tuft shorter, less conspicuous.

Sigmodon alstoni (Thomas, 1881) -- Hershkovitz (1955); Linares (1998); Peppers \& Bradley (2000)

Material examined: MHNLS M-11902; MHNLS M-11906 - 11909

Description: Ears are dark brown, rounded and well visible; small auditory bullae. Unconstricted inter-orbital region; incisive foramina that usually extend to or between molar alveoli. Unconstricted palatal bridge; posterior palatal foramina always bordered by both maxillary and palatine bones; derived stapedial circulation. Upper molars with opposite, obtusely rounded cusps; and first mandibular molars with only three well-developed roots.

Zygodontomys brevicauda (Allen \& Chapman, 1893) -- Voss (1991); Mattevi et al. (2002); Bonvicino et al. (2003)

Material examined: MHNLS M-11898 - 11901; MHNLS M-11903

Description: Short, dense and smooth pelage. Dorsal pelage brownish grayish finely marbled with some gray hairs; and light gray belly. Tail thin and bicolored, which is shorter than body length (132-144 mm). Length of hindfoot $<28 \mathrm{~mm}$, upper molars $<4.5 \mathrm{~mm}$, and breadth of braincase $<12.1 \mathrm{~mm}$. Slightly less hypsodont molars, less oblique mures and murids, more opisthodont upper incisors, deeper zygomatic notches, and more inflated nasolacrimal capsules.

Family Caviidae Fischer de Waldheim, 1817

Hydrochoeris isthmius Goldman, 1912 -- Handley (1966); Mones (1991)

Description: Size small (Smaller than H. hydrochaeris), head and body length $<1$ $\mathrm{m}$. Pelage color ranges from dark reddish to dull clay color, usually darker above than below. The ears and feet are brownish. Eye rings, sides of muzzle, and spots at base of ears paler. Skull with pterygoid processes shorter, thicker, and more rounded, less produced posteriorly. Premaxillae with posteriorly extended portions reaching to near posterior plane of incisive foramina.

Family Cuniculidae Miller et Gidley, 1918

Cuniculus paca (Linnaeus, 1766) -- Cabrera (1961); Hall (1981); Pérez (1992)

Description: Chestnut red to dark brown upperparts with three or four lines of large white spots, often coalescing into stripes, from sides of neck to rump; lower cheeks, throat, chest, and venter white. Pelage is short and sparse; spots aligned in rows largely on sides; plantar surfaces smooth. Zygoma more greatly expanded laterally, compressing the infraorbital foramen as viewed from the front; nasals short.

Family Erethizontidae Bonaparte, 1845

Coendou prehensilis (Linnaeus, 1758) -- Emmons \& Feer (1997): 217; Alberico et al. (1999); Voss \& da Silva (2001)

Description: Dorsal pelage does not include bristle-quills intermingled with defensive quills; tail longer (> 50\%) than head and body. Long tricolored quills (with white tips) intermingled with shorter bicolored quills over most of the dorsal surface, including the rump. Dorsal quills decrease gradually in length from upper back to rump, without abrupt transition. Mesopterygoid fossa usually extends anteriorly between third molars.

Family Echimyidae Gray, 1825

Proechimys canicollis (J. A. Allen, 1899) -- Gardner \& Emmons (1984); Patton (1987)

Material examined: MHNLS M-11953 (Figure 3b)

Description: Distribution non- Amazonian. Head and body length moderate to large, usually < $250 \mathrm{~mm}$. Dorsal color grayish; pelage very soft, aristiform spines narrow with long whip- like tip; tail with very narrow scale annuli. Rostrum short and broad; postorbital process of zygoma well-developed; upper and lower molars always with two folds.

Order Lagomorpha Brandt, 1855

Family Leporidae Fischer, 1817

Sylvilagus floridanus (Allen, 1890) -- Gureev (1964); Chapman et al. (1980); Hall (1981)

Material examined: MHNLS M-11897

Description: Is a mid-sized rabbit weighing approximately $1-2 \mathrm{~kg}$. Five toes are present on the forefeet, and four on the hind feet. The dorsal portion of the body varies in color from grays to browns with the tips of each hair being white or silver giving the pelage a frosty look. A distinct rust-colored patch can be seen on the nape of the neck and fronts of the forearms. The ventral portions are cleaner than back. The short, fluffy tail is grayish above and white below.

Order Carnivora Bowdich, 1821

Family Canidae Fischer, 1817

Urocyon cinereoargenteus (Schreber, 1775) -- Van Gelder (1978); Hall (1981); Fritzell \& Haroldson (1982)

Description: Short and dense hair with bright grayish color on the back and reddish towards the sides and extremities. The belly, throat and cheeks are clearly white and orange. The tail is very thick and hairy, and it is bicolored with a dark dorsal stripe until the tip. It has two thin black stripes around the eyes.

Family Felidae Fischer, 1817

Leopardus pardalis (Linnaeus, 1758) -- J. A. Allen (1919); Cabrera (1958); Weigel (1961); Hemmer (1978); Kratochvíl (1982); Murray \& Gardner (1997) Description: It is the second largest cat $(8-14 \mathrm{~kg})$ in America with an obvious patches pattern. Populations are yellow or reddish yellow on the back, while the belly is lighter. Features a striped design with rosettes and with black specks on the inside, which run parallel to each other along the body. The tail does not reach 50\% of the head-to-body length, and at first sight seems shorter than the hind legs. The limbs are large, finger-grained and with the hands broader than the legs. The canines are long and well-developed. It presents a truncated face, condition observed more clearly in lateral view.

\section{Mammalogy Notes | Notas Mastozoológicas \\ Sociedad Colombiana de Mastozoología \\ Vol. 4 Num. 2| 2018}


Leopardus tigrinus (Schreber, 1775) -- J. A. Allen (1919); Pocock (1941); Cabrera (1957); Weigel (1961); Hemmer (1978); Hall (1981); Kratochvíl (1982); Murray \& Gardner (1997)

Description: It has a small size with shape of a domestic cat. Its color is yellow to yellow-brown on the back and sides, white on the belly and chest, accompanied by black stripes and black rosettes. These rosettes consist on the back of a dark yellow ring surrounded by a black ring, while the ventral rosettes are simple and black. It has eyes border and muzzle of white color. Its tail represents the $50 \%$ of body length. The legs and hands are short and digitrified. Cranial box is slightly convex and narrow, flat front area.

Puma concolor (Linnaeus, 1771) -- Currier (1983); Pocock (1917); Weigel (1961); Hemmer (1978); Kratochvíl (1982); Culver et al. (2000)

Description: Large size (>25 kg). It has a uniform dorsal pelage, with colorations ranging from light brown to dark brown, while ventral pelage is fur cream color. It has white color under the nose and throat, black on the side and upper side of the muzzle and at the posterior base of the ears. The tail is large and cylindrical, with a dark brown or black tip and approximately $30 \%$ of the total length of the animal. The skull is rounded and short.

Puma yagouaroundi (E. Geoffroy Saint-Hilaire, 1803) -- Lacépède (1809); Desmarest (1816); Weigel (1961); Hemmer (1978); Kratochvíl (1982); Oliveira (1998)

Description: It has short, dense and rigid pelage. Its body has homogenous coloration, which may be brown, grayish brown, reddish brown, yellow or black. Its tail length is greater than $60 \%$ of body length. The legs and hands are short and digitrified. It has narrow skull and short facial area (about $20 \%$ of skull length). They have a differentiated and deep pit between the internal back and the anterior part of the interfrontal sagittal sutures.

Family Mephitidae Bonaparte, 1845

Conepatus semistriatus (Boddaert, 1784) -- Cabrera (1957)

Description: They have long body with short legs, with dark brown to black color Their pelage is dense and rough. Their feet and hands have long, strong and black claws. They have a white band from the head to the shoulders, and two paralle bands on the lower back, separated by a black band. The tail is usually erect, short (about half head-to-body length), spongy, and wholly white with black base. Their head are conical, long and bare muzzle. Their short, black ears with white hairs at base.

Family Mustelidae Fischer, 1817

Lontra longicaudis (Olfers, 1818) -- Pohle (1920); Cabrera (1957); Harris (1968); Van Zyll de Jong (1972); Hall (1981); Larivière (1999)

Description: Its pelage is dense and lustrous brown. Dorsal pelage is darker than the muzzle, upper lip, mandible and belly. Its ears are short and rounded. Its tail reaches approximately $70 \%$ of the body length, is wide, cylindrical and gradually decreases in thickness towards the tip. Its feet have well-developed inter-digital membranes

Family Procyonidae Gray, 1825

Procyon cancrivorus (Cuvier, 1798) -- Cabrera (1957)

Material examined: MHNLS M-11960 (Figure 3c)

Description: It has medium size with height about $23 \mathrm{~cm}$. Dorsal pelage short and dark brown to gray; short and thick pelage on the neck. Its face has a white line followed by and mask (white and black) that pierces the eyes. Its tail is cylindrical and shorter than body length, with dark rings. Slightly pointed ears, and dark colored legs.

Order Primates Linnaeus, 1758

Family Atelidae Gray, 1825

Alouatta seniculus (Linnaeus, 1766) -- Minezawa et al. (1985); Rylands \& Brandon-Jones (1998); Groves (2001)

Material examined: Figure 3d

Description: The color is a deep reddish-brown. Their faces are surrounded by fur and they have stubby noses. They have a long prehensile tail $>50 \mathrm{~cm}$, which is covered with fur except for the last third of the underside -allowing it to grab branches. They are bearded and with a very prominent throat. The jawbone is large, especially the body of the mandible. The position of the foramen magnum is very posterior to make way for the expanded jaw and enlarged hyoid bone.

Family Cebidae Bonaparte, 1831

Cebus albifrons (Humboldt, 1812) -- Hernández-Camacho \& Cooper (1976)

Description: This primate is a medium-sized monkey with a light brown back and a creamy white underside. Its pelage is moderately large and loose. Head light brown to dark with a medial black narrow line, and white cheeks. Tail is long, prehensile and very hairy
Order Chiroptera Blumenbach, 1779

Family Emballonuridae Gervais, 1856

Rhynchonycteris naso (Wied-Neuwied, 1820) -- Plumpton \& Jones (1992); Emmons (1997)

Material examined: MHNLS M-11934 (Figure 3i)

Description: It is small size, weighing 2.1-4.8 gr. Its color is gray with light brown given mottled appearance. No demarcation between basisphenoid pit and basioccipital; forearm sparsely haired and adorned with tufts of whitish hair; calcar much longer than tibia.

Saccopteryx bilineata (Temminck, 1838) -- Simmons \& Voss (1998); Yancey et al. (1998)

Material examined: MHNLS M-11962

Description: Supraorbital ridge continuous with postorbital process. Dorsum usually with two pale, more-or-less distinct, longitudinal stripes. Wings attached to tibia; pair of dorsal stripes clearly evident. Dorsal pelage and wing membranes blackish brown; pair of longitudinal dorsal stripes conspicuous; wing sac large and prominent (especially in males); forearm more than $44 \mathrm{~mm}$; maxillary toothrow usually more than $7 \mathrm{~mm}(6.4-7.4 \mathrm{~mm})$; greatest width across molars more than 7 $\mathrm{mm}$.

Family Noctilionidae Gray, 1821

Noctilio albiventris Desmarest, 1818 -- Davis (1976); Hood \& Pitocchelli (1983); Simmons \& Voss (1998); Lewis-Oritt et al. (2001)

Material examined: MHNLS M-11941 - 11942; MHNLS M-11963-11976

Description: Wing span about $400 \mathrm{~mm}$; length of foot $20 \mathrm{~mm}$ or less; forearm less than $70 \mathrm{~mm}$; length of maxillary toothrow 8.5 mmor less.

Family Phyllostomidae Gray, 1825

Lonchorhina aurita Tomes, 1863 -- Jones \& Carter (1976); Lassieur \& Wilson (1989); Handley \& Ochoa (1997)

Material examined: MHNLS M-11980 (Figure 3f)

Description: Smaller: greatest length of skull less than $21.5 \mathrm{~mm}$; rostrum shorter narrower, and lower than $7.1 \mathrm{~mm}$; breadth across upper canines less than $4.7 \mathrm{~mm}$; rostral breadth less than $5.6 \mathrm{~mm}$, and rostral depth less than $6.6 \mathrm{~mm}$. Forearm more than $47 \mathrm{~mm}$; third metacarpal more than $48 \mathrm{~mm}$; greatest length of skull more than $20.5 \mathrm{~mm}$; forearm and proximal portion of noseleaf hairy.

Micronycteris hirsuta (Peters, 1869) -- Sanborn (1949); Simmons (1996) Material examined: MHNLS M-11946 (Figure 31)

Description: Color of venter dark, approximates color of dorsum. Its tail protruding from the uropatagium. Forearm longer than $41 \mathrm{~mm}$; greatest length of skull more than $21 \mathrm{~mm}$; lower incisors narrow and high crowned.

Micronycteris megalotis (Gray, 1869) -- Brosset \& Charles-Dominique (1990); Alonso-Mejia \& Medellín (1991); Simmons (1996); Simmons \& Voss (1998) Material examined: MHNLS M-11914

Description: Ear from notch usually more than $22 \mathrm{~mm}$; fur on lower third of medial surface of pinna 8-10 $\mathrm{mm}$ in length. Their tail extends to the middle of uropatagium.

Micronycteris microtis Miller, 1898 -- Brosset \& Charles-Dominique (1990); Simmons (1996), Simmons \& Voss (1998)

Material examined: MHNLS M-11913; MHNLS M-11917

Description: Ear less than $22 \mathrm{~mm}$; fur on lower third of medial edge of pinna $8 \mathrm{~mm}$ or shorter.

Micronycteris minuta (Gervais, 1856) -- Simmons (1996); Simmons \& Voss (1998); López-González (1998)

Material examined: MHNLS M-11916

Description: First and second phalanges of digit IV approximately equal in length; no hairless fossa or pit on top of head. Color of venter pale gray or pale buff; basal $1 / 3$ to $1 / 2$ of fur on upper back white. Calcar shorter than foot, thumb normal.

Micronycteris schmidtorum Sanbom, 1935 -- Ascorra et al. (1991); Simmons (1996); Simmons \& Voss (1998)

Material examined: MHNLS M-11915, MHNLS M-11955 (Figure 3k)

Description: Calcar longer than foot; zygomatic breadth narrower than breadth of braincase Tibia longer than $14.5 \mathrm{~mm}$; fur on lower third of medial edge of pinna $5 \mathrm{~mm}$ or more.

Gardnerycterys crenulatum (Geoffroy Saint Hilaire, 1810) -- Handley (1960); Koopman (1978); Jones \& Carter (1979); Grubb (2001)

Material examined: MHNLS M-11918 - 11919, MHNLS M-11947 - 11951 (Figure 3g)

Description: Margin of noseleaf crenulated and fringed with straight hairs; wing membrane attached to side of foot; forearm $45-51 \mathrm{~mm}$; greatest length of skull 21 - $23 \mathrm{~mm}$. Dorsal fur grayish to blackish brown; pale, usually white, dorsal stripe along midline (may be faint in some individuals); no vertical groove between protocone and hypocone on lingual cingulum of molars 1 and 2.

\section{Mammalogy Notes | Notas Mastozoológicas \\ Sociedad Colombiana de Mastozoología \\ Vol. 4 Num. 2| 2018}




\section{Inventarios | Inventories}

Phyllostomus discolor Wagner, 1843

Material examined: MHNLS M-11981

Description: Length of calcar shorter than length of hind foot; length of ear (from notch) less than $25 \mathrm{~mm}$; sagittal crest absent or weakly developed; first upper and lower incisors broad (wider than high).

Lophostoma silvicolum (D'Orbigny, 1836) -- Davis \& Carter (1978); Medellín \& Arita (1989); Wilson \& Reeder (2005)

Material examined: MHNLS M-11920 - 11926, MHNLS M-11952 (Figure 3h)

Description: May or may not have white postauricular patches; ventral pelage pale, often strongly frosted white; anterior surface of second upper premolar overlaid by first upper premolar; population in western Ecuador has conspicuous white postauricular patches and a whitish venter.

Trachops cirrhosus (Spix, 1823) -- Cramer et al. (2001)

Material examined: MHNLS M-11983

Description: They are medium-sized (forearm 58-65 mm, greatest length of skull $27-31 \mathrm{~mm}$ ). They have presence of papilla-like protuberances on the chin and lips and by the finely serrated margins of the noseleaf. The tail extends to the middle of the interfemoral membrane and the calcar is about the same length as the foot. Their dental formula is $2 / 2,1 / 1,2 / 3,3 / 3 \times 2=34$.

Glossophaga longirostris Miller, 1898 -- Koopman (1958); Jones \& Carter (1976); Webster \& Handley (1986); Handley \& Webster (1987); Webster et al. (1998); Soriano et al. (2000); Timm \& Genoways (2003)

Material examined: MHNLS M-11943 - 11945; MHNLS M-11954; MHNLS M11958 - 11959

Description: Lower incisors not crowded. Rostrum approximately equal to braincase in length; lower incisors well developed, usually spaced evenly, and not separated medially by a conspicuous gap.

Artibeus planirostris Spix, 1823 -- Sanchez \& Lew (2012)

Material examined: MHNLS M-11979

Description: Interfemoral membrane practically naked, and not fringed medially; horseshoe of noseleaf with lower rim and usually free from upper lip; wing tips pale; maxillary toothrows convergent anteriorly; lateral margins of rostrum convergent posteriorly. Facial stripes present but weakly defined. Fur shorter, gray to gray brown; tubercles on lower lip larger, always more than 4 on each side of chin. Forearm more than $61 \mathrm{~mm}$; length of skull more than $29.5 \mathrm{~mm}$; breadth across upper molars more than $14 \mathrm{~mm}$.

Sturnira lilium (Geoffroy St. Hilaire, 1810) -- Jones \& Phillips (1976); Genoways (1998); Timm \& Genoways (2003)

Material examined: MHNLS M-11982

Description: Forearm $45.5 \mathrm{~mm}$ or less; greatest length of skull $20.0-24.5 \mathrm{~mm}$; tips of inner upper incisors narrow, often pointed; zygomatic breadth less than $14 \mathrm{~mm}$. Maxillary ramus of zygomatic arch noticeably bowed outward; zygomatic arches not converging anteriorly; maxillary toothrows arched outward (not parallel)

Desmodus rotundus (E. Geoffroy, 1810) -- Greenhall et al. (1983) Material examined: MHNLS M-11912; MHNLS M-11935 - 11940 (Figure 3j) Description: Thumb greatly elongated, longer than hind foot, and with two basal pads. Uropatagium sparsely haired. Wing membranes normally lack white markings. Coronoid process is anterior to ventral bend in ramus. Inner lower incisors bilobate; one upper molar on each side.

Diphylla ecaudata Spix, 1823 -- Greenhall et al. (1984)

Description: Thumb shorter than $13 \mathrm{~mm}$ and lacking a basal pad. Uropatagium well furred; coronoid process posterior to ventral bend in ramus; lower incisors broad with no central gap between them; two upper incisors and two lower molars on each side.
Family Molossidae Gervais, 1856

Molossus molossus (Pallas, 1766) -- Cabrera (1958); Hall \& Kelson (1959); Husson (1962); Varona (1974); Genoways et al. (1981); Dolan (1989); Simmons \& Voss (1998); Timm \& Genoways (2003)

Material examined: MHNLS M-11894; MHNLS M-11895; MHNLS M-11956 11957

Description: Forearm 35 - 40 mm; and condylobasal length less than $16 \mathrm{~mm}$.

Family Vespertilionidae Gray, 1821

Myotis nigricans (Schinz, 1821) -- Bogan (1978); Corbet \& Hill (1980); LópezGonzález et al. (2001)

Material examined: MHNLS M-11896

Description: No fringe on uropatagium; little or no frosting on dorsal hairs. Angle of slope of frontals variable; size moderate to small; forearm usually less than 40 $\mathrm{mm}$; greatest length of skull usually less than $14.5 \mathrm{~mm}$ Fur rarely longer than $4 \mathrm{~mm}$; fur weakly to moderately bicolored, often blackish.

\section{Order Pilosa Flower, 1883}

Family Bradypodidae Gray, 1821

Bradypus variegatus Schinz, 1825

Description: No mane present; facial hair shorter, contrasting in color with dorsal body hair. Pelage with blotches of pale color on darker dorsum. Males have a speculum (mid-dorsal patch of short hair containing a black median stripe border by yellow -or orange-stained hair). Throat and sides of face brown. Prominent dark brown forehead and suborbital stripe outline paler color of eye patch on face. Skull larger and mandibular spout shorter.

\section{Family Myrmecophagidae Gray, 1825}

Tamandua mexicana (Saussure, 1860)

Description: Fourth digit on manus conspicuous. Rostrum $50 \%$ or less than condylonasal length of skull. Size intermediate, total length of adults less than 1.3 $\mathrm{m}$; tail nearly naked along distal three-quarters of its length. Four pairs of orbital foramina (foramen rotundum and orbital fissure separate); posterior border of infraorbital foramen symmetrical and crescent shaped; body with black vest contrasting with pale background.

\section{Order Cingulata Illiger, 1811}

Family Dasypodidae Gray, 182

Dasypus novemcinctus Linnaeus 1758 -- McBee \& Baker (1982)

Description: Relatively rigid carapace with eight movable bands; margins of scutes of movable bands overlapped by triangular scales; rosettes of rounded scutes on scapular and pelvic shields; foreclaws moderate in size; tail long, over $55 \%$ of headand-body length, and with slender tip; rostrum long, 55\% or more of condylonasal length; condyloid process much shorter than coronoid process. No enlarged scutes on knee. Carapace with only inconspicuous, sparse hair. Length of head and body more than $360 \mathrm{~mm}$.

\section{Order Perissodactyla Owen, 1848 \\ Family Tapiridae Burnett, 1830}

Tapirus terrestris (Linnaeus 1758) -- Hershkovitz (1954); Cabrera (1961); Padilla \& Dowler (1994)

Description: It is dark brown, pale in the face, and has a low, erect crest running from the crown down the back of the neck. The round, dark ears have distinctive white edges. Newborn tapirs have a dark brown coat, with small white spots and stripes along the body. The South American tapir can attain a body length of 1.8 to $2.5 \mathrm{~m}$ with a 5 to $10 \mathrm{~cm}$ short stubby tail and an average weight around $225 \mathrm{~kg}$.

\section{Mammalogy Notes | Notas Mastozoológicas \\ Sociedad Colombiana de Mastozoología \\ Vol. 4 N um. 2| 2018}

